\title{
EFEK AKTIVITAS FISIK DAN LATIHAN PADA PENDERITA PENYAKIT HUNTINGTON: SYSTEMATIC REVIEW
}

\author{
Farahdina Bachtiar ${ }^{1^{*}}$, Condrowati ${ }^{2}$ \\ 1-2UPN Veteran Jakarta \\ Email Korespondensi: farahdinabachtiar@upnvj.ac.id \\ Disubmit: 23 Januari 2022 Diterima: 25 Januari 2022 Diterbitkan: 01 Februari 2022 \\ DOI: https://doi.org/10.33024/mnj.v5i2.5895
}

\section{ABSTRACT: PHYSICAL ACTIVITY AND EXERCISE IN PEOPLE WITH HUNTINGTON'S DISEASE: A SYSTEMATIC REVIEW}

Introduction: Huntington's disease $(H D)$ is a progressive neurodegenerative disease, characterized by the appearance of clinical symptoms such as motor, cognitive, and psychiatric disorders. Several previous studies have shown that increasing physical activity and delivering exercise to people with $H D$ has a positive impact, particularly in everyday tasks.

Purpose: This study aims to investigate and discuss the published literature related to the evidence of physical activity and exercise benefits for people with HD.

Methods: Electronic databases, including Ovid Medline, Embase, Embase Classic, PsycINFO, PEDro database for physiotherapy trials, and Google Scholar, were used to carry out comprehensive literature searches in October 2021.

Results: There were twelve studies that met inclusion criteria from the total of twenty-two identified articles. Each study discussed a different type of physical activity, including balance and transition training, gait training, Activities of Daily Living ( $A D L)$, cognitive function training, gym, and games-based exercise. The duration of the intervention ranged from six weeks to two years.

Conclusion: Most studies in this review report improvements of the individuals with HD in the early to the middle stage after doing physical activity and exercise in terms of gait ability, balance, fitness, and motor function, as well as daily living activity. Large clinical trials with improved reporting are required in future research.

Keywords: physical activity, exercise, Huntington disease's, HD, physiotherapy 


\section{INTISARI: EFEK AKTIVITAS FISIK DAN LATIHAN PADA PENDERITA PENYAKIT HUNTINGTON: SYSTEMATIC REVIEW}

Pendahuluan: Penyakit Huntington (HD) merupakan penyakit neurodegeneratif yang bersifat progresif, ditandai dengan munculnya gejala klinis seperti gangguan motorik, kognitif, dan kejiwaan. Beberapa hasil penelitian sebelumnya menunjukkan bahwa aktivitas fisik serta pemberian latihan memiliki efek yang positif pada penderita HD, terutama dalam melakukan aktivitas kehidupannya sehari-hari.

Tujuan: Tujuan dari penelitian ini adalah untuk mencari bukti serta mengidentifikasi pengaruh aktivitas fisik dan latihan bagi penderita HD.

Metode Penelitian: Penelusuran literatur secara komprehensif dilakukan pada bulan Oktober 2021. Adapun basis data elektronik yang digunakan meliputi Ovid Medline, Embase, Embase Classic, PsycINFO, PEDro database for physiotherapy trials, dan Google Scholar.

Hasil: Terdapat dua belas penelitian yang memenuhi kriteria inklusi dari total dua puluh dua artikel yang teridentifikasi. Setiap penelitian membahas jenis aktivitas fisik yang berbeda, termasuk latihan keseimbangan dan transisi, latihan berjalan, Aktivitas Kehidupan Sehari-hari (AKS), latihan fungsi kognitif, gym, dan latihan berbasis permainan. Durasi intervensi berkisar dari enam minggu hingga dua tahun.

Kesimpulan: Secara keseluruhan, sebagian besar penelitian dalam review ini melaporkan peningkatan individu dengan HD pada tahap awal hingga menengah setelah melakukan aktivitas fisik dan latihan. Peningkatan terjadi dalam hal kemampuan berjalan, keseimbangan, kebugaran, dan fungsi motorik, serta aktivitas hidup sehari-hari. Uji klinis dalam skala yang lebih besar dengan pelaporan yang lebih baik masih dibutuhkan di masa depan.

Kata kunci: aktivitas fisik, latihan, penyakit Huntington, HD, fisioterapi

\section{PENDAHULUAN}

Fisioterapi merupakan suatu pelayanan kesehatan yang menjanjikan bagi individu yang menderita penyakit neurodegeneratif seperti penyakit Huntington (HD) (Petzinger et al., 2013). Beberapa bukti menunjukkan bahwa latihan dan aktivitas fisik bermanfaat pada penderita HD, khususnya dalam hal fungsi motorik dan berbagai parameter fisik dan sosial lainnya. Penyakit Huntington, juga dikenal sebagai HD, adalah penyakit neurodegeneratif yang diturunkan secara progresif yang ditandai dengan munculnya gejala klinis seperti disfungsi motorik, kognitif, dan psikiatri (Borgs et al., 2012; Quinn et al., 2020). Usia onset HD bervariasi, tetapi biasanya terjadi pada usia paruh baya dengan rata-rata usia 40 tahun (Myers, 2004; Weydt et al., 2014).

Penyakit

Huntington disebabkan oleh kesalahan gen yang menyebabkan bagian-bagian otak memburuk secara bertahap dari waktu ke waktu (NHS, 2021). Selain mengalami gangguan pergerakan berupa chorea, individu dengan HD dapat mengalami kontraktur otot dan sendi (pemendekan otot yang tidak normal yang membatasi gerakan sendi) (Huntington's Disease Society of America). Perawatan farmakologis saat ini untuk HD ditujukan untuk mengurangi gerakan chorea yang tidak disengaja. Obatobatan seperti antipsikotik, tetrabenazine (TBZ), dan selective serotonin reuptake inhibitor (SSRI) 
telah digunakan dalam pengobatan pasien HD (Aleksandar, 2013). Namun, tidak ada intervensi yang terbukti dapat mengubah perkembangan penyakit atau secara efektif mengatasi gangguan motorik (Fritz et al., 2017).Meskipun demikian, aktivitas fisik dan latihan dapat membantu memfasilitasi aktivitas fungsional secara mandiri dalam kehidupan sehari-hari pada pasien HD (Bilney et al., 2003; Frank, 2014, NHS, 2014).

Beberapa penelitian telah menunjukkan bahwa aktivitas fisik bermanfaat bagi penderita HD. Menurut Trembath et al (2010), gaya hidup sedentari berkontribusi terhadap timbulnya gejala HD lebih dini. Dalam penelitian tersebut disimpulkan bahwa dengan menghindari gaya hidup pasif dapat memiliki pengaruh yang signifikan dalam memperlambat onset pada penderita HD (Trembath et al., 2010). Selanjutnya, sebuah penelitian menggunakan sampel hewan menemukan bahwa latihan dapat meningkatkan fungsi kognitif dan motorik pada hewan yang mengalami HD. Pemberian latihan pada tikus R6/1 dapat mengurangi terjadinya kehilangan sel striatal dan meningkatkan ukuran neuronal intra-nuclear, yang bermanfaat untuk penderita HD (Harrison et al., 2013).

Di Indonesia, masih kurang atau bahkan belum ada penelitian yang membahas mengenai efek aktivitas fisik dan latihan bagi penderita HD. Selain itu, beberapa penelitian yang sudah dilakukan di dunia melaporkan hasil yang berbeda-beda. Oleh karena itu, penulis tertarik melakukan tinjauan sistematis untuk membahas mengenai efek aktivitas fisik berbasis latihan bagi penderita HD.

\section{METODOLOGI PENELITIAN}

Penelitian ini menggunakan metode Systematic Literature Review (SLR). Pencarian literature menggunakan database berupa Ovid Medline, Embase, Embase Classic, PsycINFO, PEDro database for physiotherapy trials, dan Google Scholar. Kata kunci yang digunakan dalam bahasa Inggris yaitu 'physical activity,' 'exercise,' 'physical therapy,' 'physiotherapy,' 'Huntington disease,' and 'HD'. Kata 'and' digunakan untuk menghubungkan kata kunci yang telah disebutkan sebelumnya.

Adapun kriterian inklusi dalam review ini yaitu:1) artikel berasal dari publikasi utama; 2) ditulis dalam bahasa Inggris; 3) penelitian menggunakan manusia (dewasa) sebagai subjek; 4) populasi dan sampel penelitian didiagnosis HD, dan 5) penelitian bertujuan untuk mengetahui aktivitas fisik dan/atau intervensi berbasis latihan pada penderita HD. Kriteria eksklusi mencakup: 1) tidak dalam teks lengkap atau hanya berupa abstrak; 2) menggunakan hewan sebagai subjek uji; dan 3) berbentuk laporan kasus, editorial, buletin, atau review. Pertanyaan penelitian dari systematic review ini adalah "Apakah aktivitas fisik dan latihan dapat mengurangi gejala dan memaksimalkan fungsi pada penderita penyakit Huntington?"

\section{HASIL PENELITIAN}

Berdasarkan pencarian literatur dari berbagai sumber, seperti yang diilustrasikan dalam diagram alur PRISMA (Gambar 1), didapatkan hasil 584 artikel. Sejumlah dua belas artikel yang diterbitkan memenuhi kriteria inklusi dan dimasukkan dalam review ini (Tabel 1).

Tabel 1 merangkum hasil penelitian yang mencakup lokasi, 
stadium $\mathrm{HD}$, rata-rata dan standar deviasi usia penderita HD, jenis dan durasi aktivitas fisik. Dapat dilihat bahwa hampir semua penelitian melibatkan penderita HD yang berada pada stadium awal hingga pertengahan penyakit, dengan usia rata-rata sekitar 50 tahun. Ukuran sampel penelitian berkisar antara 10 hingga 40 peserta. Sebagian besar sampel penelitian dalam review ini adalah penderita HD pada tahap awal hingga menengah.

Setiap penelitian membahas jenis aktivitas fisik yang berbeda, seperti latihan keseimbangan dan transisi, latihan berjalan, Aktivitas Kehidupan Sehari-hari (AKS), dan latihan fungsi kognitif, gym, dan latihan berbasis permainan. Durasi intervensi berkisar dari 6 minggu hingga 2 tahun. Ukuran hasil yang digunakan dalam setiap penelitian ditentukan oleh jenis intervensi yang digunakan.

Tabel 2 menunjukkan critical appraisal (penilaian kritis) penelitian. Berdasarkan data, terdapat satu penelitian yang bersifat eksperimental (time-series), tiga penelitian adalah Randomized controlled trials (RCT), dua penelitian menggunakan desain quasi-eksperimental, dua penelitian berupa feasibility study, dua penelitian prospektif, dan dua pilot study. Secara umum, sebagian besar penelitian menunjukkan bahwa individu dengan $\mathrm{HD}$, baik pada tahap awal maupun menengah, mengalami peningkatan fungsi setelah melakukan latihan dan aktivitas fisik.

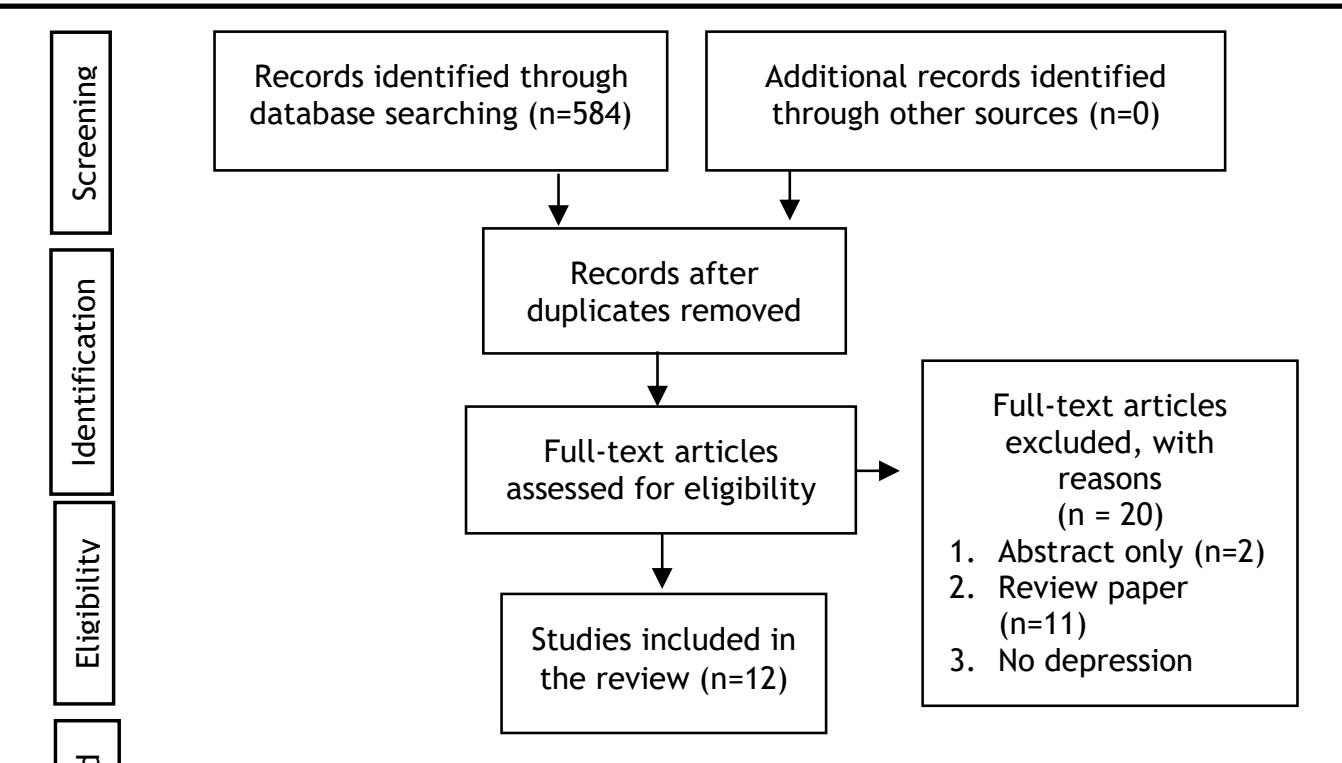

Diadaptasi dari: Moher D, Liberati A, Tetzlaff J, Altman DG, The PRISMA Group. (2009) Preferred Reporting Items for Systematic Reviews and Meta-Analyses: The PRISMA Statement. PLoS Med 6 (7): e1000097.

Gambar 1. Flowchart Strategi Pencarian dan Kriteria Seleksi menggunakan Pedoman PRISMA Guideline 
Tabel 1. Aktivitas Fisik pada Penderita HD

\begin{tabular}{|c|c|c|c|c|}
\hline \multirow{2}{*}{$\begin{array}{l}\text { Peneliti, } \\
\text { Tahun dan } \\
\text { Lokasi } \\
\text { Penelitian }\end{array}$} & \multicolumn{2}{|r|}{ HD } & \multicolumn{2}{|c|}{ Aktivitas fisik } \\
\hline & Tahap & $\begin{array}{l}\text { Usia rata-rata } \\
\text { (SD) }\end{array}$ & Jenis & Durasi \\
\hline $\begin{array}{l}\text { Bohlen et } \\
\text { al. (2013) } \\
\text { Swedia }\end{array}$ & $\begin{array}{l}\text { tahap awal } \\
\text { hingga } \\
\text { menengah }\end{array}$ & 52,17 tahun & $\begin{array}{l}\text { Latihan transfer; } \\
\text { stabilitas postur; latihan } \\
\text { keseimbangan; } \\
\text { latihan berjalan; latihan } \\
\text { koordinasi motorik }\end{array}$ & $\begin{array}{l}\text { lebih dari } 6 \\
\text { minggu }\end{array}$ \\
\hline $\begin{array}{l}\text { Busse et } \\
\text { al. (2013) } \\
\text { Cardiff } \\
\text { dan } \\
\text { Oxford, } \\
\text { Inggris }\end{array}$ & $\begin{array}{l}\text { tahap awal } \\
\text { hingga } \\
\text { menengah }\end{array}$ & $\begin{array}{l}50.4 \\
(S D \pm 11,4) \text { tahun }\end{array}$ & $\begin{array}{l}\text { Gym (latihan aerobik dan } \\
\text { anaerobik); program } \\
\text { jalan kaki berbasis rumah }\end{array}$ & 12 minggu \\
\hline $\begin{array}{l}\text { Ekwall } \\
(2011) \\
\text { Swedia }\end{array}$ & $\begin{array}{l}\text { tahap awal } \\
\text { hingga } \\
\text { menengah }\end{array}$ & $52(\mathrm{SD}=16)$ tahun & $\begin{array}{l}\text { Latihan transisi, } \\
\text { keseimbangan, dan } \\
\text { efikasi diri terkait jatuh }\end{array}$ & 6 minggu \\
\hline $\begin{array}{l}\text { Frese et } \\
\text { al. (2017) } \\
\text { Swiss }\end{array}$ & $\begin{array}{l}\text { tidak } \\
\text { digambarkan }\end{array}$ & $\begin{array}{l}\text { Kelompok } \\
\text { kontrol=49,1 } \\
(6,8) \\
\text { tahun; kelompok } \\
\text { intervensi=54,8 } \\
(7,1) \text { tahun }\end{array}$ & $\begin{array}{l}\text { Kedua kelompok=latihan } \\
\text { endurance dibagi } \\
\text { menjadi tiga periode } \\
\text { latihan ( } 10 \text { minggu=30 } \\
\text { menit bersepeda } \\
\text { intensitas konstan, tiga } \\
\text { kali seminggu dengan } \\
\text { total } 8 \\
\text { minggu=bersepeda } \\
\text { intensitas tinggi, } 6 \\
\text { minggu= dua sesi interval } \\
\text { dan latihan beban } \\
\text { konstan, minggu } \\
\text { regenerasi= dua latihan } \\
\text { beban konstan }\end{array}$ & 6 bulan \\
\hline
\end{tabular}

\begin{tabular}{|c|c|c|c|c|}
\hline $\begin{array}{l}\text { Khalil et } \\
\text { al. (2013) } \\
\text { Cardiff }\end{array}$ & $\begin{array}{l}\text { tahap awal } \\
\text { hingga } \\
\text { menengah }\end{array}$ & $\begin{array}{l}54,2(\mathrm{SD}=9,9) \\
\text { tahun }\end{array}$ & $\begin{array}{l}\text { Program latihan di rumah } \\
\text { (latihan menggunakan } \\
\text { DVD) }\end{array}$ & 8 minggu \\
\hline $\begin{array}{l}\text { Kloos et } \\
\text { al. (2013) } \\
\text { Amerika } \\
\text { Serikat }\end{array}$ & $\begin{array}{l}\text { tahap awal } \\
\text { hingga } \\
\text { menengah }\end{array}$ & $\begin{array}{l}50,7(\mathrm{SD}=14.7) \\
\text { tahun }\end{array}$ & $\begin{array}{l}\text { Game Dance Dance } \\
\text { Revolution }\end{array}$ & 6 minggu \\
\hline $\begin{array}{l}\text { Mueller et } \\
\text { al. (2017) } \\
\text { Swiss- } \\
\text { tanah }\end{array}$ & $\begin{array}{l}\text { tidak } \\
\text { digambarkan }\end{array}$ & $\begin{array}{l}\text { Kelompok } \\
\text { kontrol=49,7 } \\
(6,8) \\
\text { tahun; kelompok } \\
\text { intervensi=53,2 } \\
(8,8) \text { tahun }\end{array}$ & $\begin{array}{l}\text { Kedua kelompok=latihan } \\
\text { ketahanan dibagi } \\
\text { menjadi tiga fase (10 } \\
\text { minggu= siklus beban } \\
\text { konstan, tiga kali } \\
\text { seminggu selama } 8 \\
\text { minggu=latihan interval } \\
\text { intensitas } \\
\text { tinggi, protokol latihan } \\
\text { ketahanan } 6 \text { minggu yang } \\
\text { terdiri dari dua sesi } \\
\text { latihan interval dan satu }\end{array}$ & 26 minggu \\
\hline
\end{tabular}




\begin{tabular}{|c|c|c|c|c|}
\hline & & & $\begin{array}{l}\text { sesi latihan beban } \\
\text { konstan }\end{array}$ & \\
\hline $\begin{array}{l}\text { Piira et al. } \\
\text { (2013) } \\
\text { Tromso }\end{array}$ & $\begin{array}{l}\text { tahap awal } \\
\text { hingga } \\
\text { menengah }\end{array}$ & $\begin{array}{l}52,4(S D \pm 13,1) \\
\text { tahun }\end{array}$ & $\begin{array}{l}\text { Latihan keseimbangan } \\
\text { dan gaya } \\
\text { berjalan; latihan } \\
\text { Aktivitas Kehidupan } \\
\text { Sehari-hari (AKS) dan } \\
\text { fungsi kognitif, latihan } \\
\text { motorik halus }\end{array}$ & $\begin{array}{l}1 \text { tahun } \\
\text { (intensif) }\end{array}$ \\
\hline $\begin{array}{l}\text { Piira et al. } \\
\text { (2014) } \\
\text { Tromso }\end{array}$ & $\begin{array}{l}\text { tahap awal } \\
\text { hingga } \\
\text { menengah }\end{array}$ & $\begin{array}{l}50.0(S D \pm 14.0) \\
\text { tahun }\end{array}$ & $\begin{array}{l}\text { Latihan di gym dan/atau } \\
\text { di kolam renang, latihan }\end{array}$ & $\begin{array}{l}2 \text { tahun } \\
\text { (intensif) }\end{array}$ \\
\hline $\begin{array}{l}\text { Quinn et } \\
\text { al. (2014) } \\
\text { Inggris }\end{array}$ & $\begin{array}{l}\text { tahap } \\
\text { menengah }\end{array}$ & $\begin{array}{l}57.0(\mathrm{SD}=10.1) \\
\text { tahun }\end{array}$ & $\begin{array}{l}\text { Latihan khusus } \\
\text { tugas/latihan berbasis } \\
\text { rumah (berjalan, transfer } \\
\text { duduk-ke-berdiri, dan } \\
\text { berdiri) }\end{array}$ & 8 minggu \\
\hline $\begin{array}{l}\text { Quinn et } \\
\text { al. (2016) } \\
\text { Inggris }\end{array}$ & $\begin{array}{l}\text { semua } \\
\text { tahapan }\end{array}$ & $\begin{array}{l}\text { Kelompok } \\
\text { kontrol=51 } \\
\text { tahun; kelompok } \\
\text { intervensi }=53 \\
\text { tahun }\end{array}$ & $\begin{array}{l}\text { Kelompok kontrol = } \\
\text { perawatan biasa, gym } \\
\text { dan latihan bersepeda di } \\
\text { rumah setelah selesainya } \\
\text { penelitian; } \\
\text { Kelompok intervensi= } \\
\text { aerobik (stationary } \\
\text { cycling) dan latihan } \\
\text { penguatan tubuh bagian } \\
\text { atas dan bawah }\end{array}$ & 12 minggu \\
\hline $\begin{array}{l}\text { Zinzi et } \\
\text { al. (2007) } \\
\text { Roma }\end{array}$ & $\begin{array}{l}\text { tahap awal } \\
\text { hingga } \\
\text { menengah }\end{array}$ & $\begin{array}{l}52.0(\mathrm{SD}=3.3) \\
\text { tahun }\end{array}$ & $\begin{array}{l}\text { Latihan pernapasan dan } \\
\text { terapi wicara; fisioterapi } \\
\text { dan okupasi dan latihan } \\
\text { rehabilitasi kognitif }\end{array}$ & $\begin{array}{l}3 \text { kali dalam } \\
\text { setahun } \\
\text { selama } 2 \\
\text { tahun }\end{array}$ \\
\hline
\end{tabular}

\section{Tabel 2. Penilaian Kritis Terhadap Penelitian Mengenai Efek Aktivitas Fisik pada Penderita HD}

\begin{tabular}{|c|c|c|c|c|c|c|c|}
\hline $\begin{array}{l}\text { Peneliti, } \\
\text { Tahun dan } \\
\text { Lokasi } \\
\text { Penelitian }\end{array}$ & $\begin{array}{l}\text { Populasi } \\
\text { (N) \& } \\
\text { Ukuran } \\
\text { sampel } \\
\text { (n) }\end{array}$ & $\begin{array}{c}\text { Desain } \\
\text { penelitian }\end{array}$ & $\begin{array}{c}\text { Sample } \\
\text { Frame }\end{array}$ & $\begin{array}{c}\text { Assessor } \\
\text { blinded }\end{array}$ & $\begin{array}{c}\text { Kriteria } \\
\text { inklusi }\end{array}$ & $\begin{array}{l}\text { Tingkat } \\
\text { respons } \\
\text { dan } \\
\text { penolakan }\end{array}$ & Hasil \\
\hline $\begin{array}{l}\text { Bohlen et } \\
\text { al. (2013) } \\
\text { Swedia }\end{array}$ & $\begin{array}{l}N=12 \\
n=12\end{array}$ & $\begin{array}{l}\text { Experimental } \\
\text { (time-series) }\end{array}$ & $\begin{array}{l}\text { Tidak } \\
\text { dijelaskan }\end{array}$ & Tidak & $\mathrm{Ya}$ & $100 \%$ & $\begin{array}{l}\text { Peningkatan yang } \\
\text { signifikan dapat dilihat } \\
\text { pada GAITRite, tes Up } \\
\text { and Go, dan Berg } \\
\text { Balance Scale; namun, } \\
\text { pengukuran force plate } \\
\text { dan Total Motor Scores } \\
\text { tetap tidak berubah } \\
\text { (efek positif pada gaya } \\
\text { berjalan) }\end{array}$ \\
\hline
\end{tabular}

\begin{tabular}{|c|c|c|c|c|c|c|c|}
\hline $\begin{array}{l}\text { Busse et } \\
\text { al. (2013) } \\
\text { Cardiff } \\
\text { dan } \\
\text { Oxford, } \\
\text { Inggris }\end{array}$ & $\begin{array}{l}N=114 \\
n=31\end{array}$ & $\begin{array}{l}\text { Randomized } \\
\text { Feasibility Study }\end{array}$ & $\begin{array}{l}\text { Klinik rawat } \\
\text { jalan }\end{array}$ & $\mathrm{Ya}$ & $\mathrm{Ya}$ & $\begin{array}{l}\text { 70,96\% } \\
\text { Penolak } \\
\text { dijelaskan }\end{array}$ & $\begin{array}{l}\text { Latihan ditoleransi } \\
\text { dengan baik dan } \\
\text { memiliki efek sedang } \\
\text { pada fungsi kognitif dan } \\
\text { mobilitas }\end{array}$ \\
\hline
\end{tabular}




\begin{tabular}{|c|c|c|c|c|c|c|c|}
\hline $\begin{array}{l}\text { Ekwall } \\
(2011) \\
\text { Swedia }\end{array}$ & $\begin{array}{l}N=20 \\
n=12\end{array}$ & $\begin{array}{l}\text { Quasi } \\
\text { Experimental } \\
\text { within-group } \\
\text { Design and } \\
\text { Correlation }\end{array}$ & $\begin{array}{l}\text { Klinik rawat } \\
\text { jalan }\end{array}$ & $\mathrm{Ya}$ & $\mathrm{Ya}$ & $\begin{array}{l}60 \% \\
\text { Penolak } \\
\text { dijelaskan }\end{array}$ & $\begin{array}{l}\text { Peningkatan yang } \\
\text { signifikan dalam } \\
\text { keseimbangan; program } \\
\text { pengobatannya efektif }\end{array}$ \\
\hline $\begin{array}{l}\text { Frese et } \\
\text { al. (2017) } \\
\text { Swiss }\end{array}$ & $\begin{array}{l}T=13 \\
T=12\end{array}$ & $\begin{array}{l}\text { Randomized } \\
\text { controlled trial }\end{array}$ & $\begin{array}{l}\text { Laboratorium } \\
\text { penelitian }\end{array}$ & $\mathrm{Ya}$ & $\mathrm{Ya}$ & $\begin{array}{l}\text { 92,30\% } \\
\text { Penolak } \\
\text { dijelaskan }\end{array}$ & $\begin{array}{l}\text { Kedua kelompok } \\
\text { menunjukkan efek yang } \\
\text { signifikan dari } \\
\text { pelatihan daya tahan } \\
\text { pada fungsi } \\
\text { kardiovaskular dan } \\
\text { stabilisasi fungsi } \\
\text { motorik }\end{array}$ \\
\hline
\end{tabular}

\begin{tabular}{|c|c|c|c|c|c|c|c|}
\hline $\begin{array}{l}\text { Khalil et } \\
\text { al. (2013) } \\
\text { Cardiff }\end{array}$ & $\begin{array}{l}N=106 \\
n=25\end{array}$ & $\begin{array}{l}\text { Randomized } \\
\text { Controlled Pilot } \\
\text { Trial }\end{array}$ & $\begin{array}{l}\text { Berbasis } \\
\text { rumah }\end{array}$ & $\mathrm{Ya}$ & $\mathrm{Ya}$ & $\begin{array}{l}84 \% \\
\text { Penolak } \\
\text { dijelaskan }\end{array}$ & $\begin{array}{l}\text { Peningkatan dalam } \\
\text { berjalan, } \\
\text { keseimbangan, fungsi, } \\
\text { dan tingkat aktivitas } \\
\text { fisik; tidak ada } \\
\text { peningkatan yang } \\
\text { signifikan pada kualitas } \\
\text { hidup }\end{array}$ \\
\hline
\end{tabular}

\begin{tabular}{|c|c|c|c|c|c|c|c|}
\hline $\begin{array}{l}\text { Kloos et } \\
\text { al. (2013) } \\
\text { Amerika } \\
\text { Serikat }\end{array}$ & $\begin{array}{l}N=49 \\
n=18\end{array}$ & $\begin{array}{l}\text { A cross-over, } \\
\text { Controlled } \\
\text { Single Blinded; } \\
\text { Feasibility } \\
\text { Study }\end{array}$ & $\begin{array}{l}\text { Berbasis } \\
\text { rumah }\end{array}$ & $\mathrm{Ya}$ & $\mathrm{Ya}$ & $\begin{array}{l}75 \% \\
\text { Penolak } \\
\text { dijelaskan }\end{array}$ & $\begin{array}{l}\text { Terjadi peningkatan } \\
\text { pada mayoritas subjek } \\
\text { penelitian } \\
\text { setelah bermain game }\end{array}$ \\
\hline $\begin{array}{l}\text { Mueller et } \\
\text { al. (2017) } \\
\text { Swiss }\end{array}$ & $\begin{array}{l}T=15 \\
n=13\end{array}$ & $\begin{array}{l}\text { Randomized } \\
\text { controlled trial }\end{array}$ & $\begin{array}{l}\text { Laboratorium } \\
\text { penelitian }\end{array}$ & $\mathrm{Ya}$ & $\mathrm{Ya}$ & $\begin{array}{l}86,67 \% \\
\text { Penolak } \\
\text { dijelaskan }\end{array}$ & $\begin{array}{l}\text { Mitokondria otot } \\
\text { rangka pasien HD } \\
\text { dalam merespon } \\
\text { stimulus latihan daya } \\
\text { tahan sama dengan } \\
\text { kelompok kontrol yang } \\
\text { sehat. Latihan daya } \\
\text { tahan adalah pilihan } \\
\text { yang aman dan layak } \\
\text { untuk meningkatkan } \\
\text { indeks metabolisme } \\
\text { energi pada otot } \\
\text { rangka pasien HD }\end{array}$ \\
\hline $\begin{array}{l}\text { Piira et al. } \\
\text { (2013) } \\
\text { Tromso }\end{array}$ & $\begin{array}{l}T=37 \\
n=31\end{array}$ & $\begin{array}{l}\text { Prospective } \\
\text { Intervention } \\
\text { Study }\end{array}$ & $\begin{array}{l}\text { Pusat } \\
\text { rehabilitasi } \\
\text { rawat inap }\end{array}$ & Tidak & $\mathrm{Ya}$ & $\begin{array}{l}83,8 \% \\
\text { Penolak } \\
\text { dijelaskan }\end{array}$ & $\begin{array}{l}\text { Peningkatan } \\
\text { keseimbangan, fungsi } \\
\text { gaya berjalan, dan } \\
\text { kualitas hidup, serta } \\
\text { pengurangan gejala } \\
\text { depresi dan kecemasan }\end{array}$ \\
\hline $\begin{array}{l}\text { Piira et al. } \\
\text { (2014) } \\
\text { Tromso }\end{array}$ & $\begin{array}{l}T=20 \\
n=10\end{array}$ & $\begin{array}{l}\text { Prospective } \\
\text { Intervention } \\
\text { Study }\end{array}$ & Rawat inap & Tidak & $\mathrm{Ya}$ & $\begin{array}{l}\text { Penolak } \\
\text { dijelaskan }\end{array}$ & $\begin{array}{l}\text { Gaya berjalan dan } \\
\text { keseimbangan } \\
\text { menunjukkan } \\
\text { penurunan yang tidak } \\
\text { signifikan. Kualitas } \\
\text { hidup pada aspek fisik } \\
\text { belum meningkat } \\
\text { secara } \\
\text { signifikan; Fungsi ADL } \\
\text { tetap stabil tanpa } \\
\text { penurunan yang }\end{array}$ \\
\hline
\end{tabular}




\begin{tabular}{|c|c|c|c|c|c|c|c|}
\hline & & & & & & & $\begin{array}{l}\text { signifikan; empat } \\
\text { peserta mengalami } \\
\text { peningkatan fungsi } \\
\text { motorik (dua peserta } \\
\text { menurun) }\end{array}$ \\
\hline $\begin{array}{l}\text { Quinn et } \\
\text { al. (2014) } \\
\text { Inggris }\end{array}$ & $\begin{array}{l}T=108 \\
n=30\end{array}$ & $\begin{array}{l}\text { Randomized } \\
\text { Controlled } \\
\text { Feasibility Trial }\end{array}$ & $\begin{array}{l}\text { Berbasis } \\
\text { rumah }\end{array}$ & $\mathrm{Ya}$ & $\mathrm{Ya}$ & $\begin{array}{l}\text { 93,3\% } \\
\text { Penolak } \\
\text { dijelaskan }\end{array}$ & $\begin{array}{l}\text { Ukuran efek tidak } \\
\text { signifikan secara } \\
\text { statistik; 92\% tujuan } \\
\text { tercapai, dan } 46 \% \\
\text { tujuan tercapai dengan } \\
\text { kesuksesan yang lebih } \\
\text { besar dari yang } \\
\text { diharapkan }\end{array}$ \\
\hline $\begin{array}{l}\text { Quinn et } \\
\text { al. (2016) } \\
\text { Inggris }\end{array}$ & $\begin{array}{l}T=314 \\
n=32\end{array}$ & $\begin{array}{l}\text { Randomized } \\
\text { controlled trial }\end{array}$ & $\begin{array}{l}\text { Rumah dan } \\
\text { rumah sakit/ } \\
\text { laboratorium } \\
\text { penelitian }\end{array}$ & $\mathrm{Ya}$ & $\mathrm{Ya}$ & $\begin{array}{l}\text { 90,63\% } \\
\text { Penolak } \\
\text { dijelaskan }\end{array}$ & $\begin{array}{l}\text { Intervensi latihan } \\
\text { jangka pendek aman } \\
\text { dan layak. Selanjutnya, } \\
\text { jika dibandingkan } \\
\text { dengan kelompok } \\
\text { kontrol, subjek pada } \\
\text { kelompok intervensi } \\
\text { tidak memiliki insiden } \\
\text { jatuh yang lebih tinggi }\end{array}$ \\
\hline $\begin{array}{l}\text { Zinzi et } \\
\text { al. (2007) } \\
\text { Roma }\end{array}$ & $\mathrm{n}=40$ & Pilot study & $\begin{array}{l}\text { Intensif, } \\
\text { rawat inap }\end{array}$ & Tidak & $\mathrm{Ya}$ & $\begin{array}{l}\text { Tidak } \\
\text { dijelaskan }\end{array}$ & $\begin{array}{l}\text { Peningkatan signifikan } \\
\text { dalam performa } \\
\text { motorik dan aktivitas } \\
\text { sehari-hari; pertahanan } \\
\text { tingkat kemampuan } \\
\text { fungsional dan kognitif } \\
\text { yang konstan }\end{array}$ \\
\hline
\end{tabular}

\section{PEMBAHASAN}

Penelitian ini menggunakan metode systematic review yang menyajikan bukti dari hasil-hasil penelitian yang telah dilakukan mengenai efek aktivitas fisik dan latihan pada penderita Huntington (HD). Exercise atau latihan fisik telah terbukti memiliki banyak manfaat bagi orang-orang dari segala usia dan setiap tingkat kebugaran dan kesehatan. Beberapa manfaatnya meliputi peningkatan konsentrasi, mood, kondisi kardiovaskular dan peningkatan kekuatan, keseimbangan serta koordinasi. 
Seseorang yang mengalami HD memiliki gangguan fisik, kognitif, dan psikologis yang berdampak negatif pada mobilitas dan partisipasi mereka dalam melakukan aktivitas hidup sehari-hari, yang selanjutnya dapat menyebabkan penurunan kualitas hidup penderitanya (Varda et al., 2016). Hasil penelitian sebelumnya menunjukkan bahwa latihan fisik bermanfaat untuk mengurangi gejala dan memaksimalkan fungsi pada penderita HD.

Terdapat dua belas penelitian yang dibahas dalam review ini. Penelitian yang dilakukan oleh Busse et al (2013) menilai fisibilitas dan manfaat dari program latihan berbasis komunitas untuk individu dengan HD dengan pemberian intervensi selama dua belas minggu. Subjek dibagi menjadi dua kelompok secara acak, yaitu kelompok kontrol dan intervensi. Kelompok kontrol diminta melanjutkan aktivitas seperti biasa dan diberikan intervensi di akhir penelitian, sedangkan kelompok intervensi diberikan program gym (baik aerobik maupun anaerobik). Dua puluh dua dari tiga puluh satu peserta menyelesaikan penelitian tersebut. Program latihan berbasis komunitas dilaporkan bermanfaat bagi pasien HD (Busse et al., 2013).

Penelitian yang dialakukan oleh Ekwall tahun 2011 berupa quasi-experimental within-group design yang melibatkan dua belas subjek dengan HD (Ekwall, 2011). Penelitian dilakukan dua kali seminggu selama enam minggu untuk menilai efek dari program latihan pada penderita HD. Hasilnya menunjukkan bahwa pada penderita $\mathrm{HD}$ yang diukur dengan Berg balance scale $(\mathrm{p}=0,045)$, terjadi peningkatan yang cukup besar pada fungsi dan keseimbangan motorik (Ekwall, 2011).
Penelitian Frese et al (2017) mengidentifikasi pengaruh latihan endurance atau daya tahan terhadap perkembangan motorik, disfungsi kognitif, dan fungsi kardiovaskular pada pasien HD. Penelitian ini merupakan desain Randomized controlled trial (RCT) yang membandingkan penderita HD dan subjek sehat. Hasil penelitian tersebut menunjukkan bahwa ada pengaruh yang signifikan pelatihan daya tahan pada fungsi motorik dan fungsi kardiovaskular, tetapi efeknya tidak ditemukan pada variabel neuropsikologis yang diteliti.

Pada review ini terdapat tiga penelitian berupa yang menginvestigasi program latihan berbasis rumah (home-based training) pada penderita HD. Penelitian pertama dilakukan oleh Khalil et al. pada dua puluh lima orang dengan HD yang diminta untuk berlatihan mengikuti instruksi dari video latihan DVD dan latihan berjalan seminggu sekali selama kurang lebih 30 menit (Khalil et al., 2013). Penelitian ini menemukan bahwa terdapat peningkatan signifikan dalam berjalan, keseimbangan, fungsi, dan tingkat aktivitas fisik. Penelitian yang dilakukan oleh Kloos menyelidiki fisibilitas, penerimaan, dan keamanan latihan video game yang diawasi yang disebut Dance Dance Revolution (Kloos et al., 2013). Latihan tersebut memerlukan langkah multi arah dengan berbagai kecepatan dan memanfaatkan gerakan tubuh sebagai salah satu elemen permainan. Terlepas dari kenyataan bahwa tidak ada efek signifikan pada mobilitas fungsional dan keseimbangan setelah enam minggu bermain game, tingkat kepatuhannya tinggi, menunjukkan bahwa game merupakan latihan yang bermanfaat bagi penderita HD. Penelitian lain melaporkan bahwa latihan berbasis rumah 
(home-based training) pada penderita HD tahap menengah memiliki effect size yang kecil pada semua alat ukur. Namun, sebagian besar tujuan terpenuhi pada akhir intervensi, dan $46 \%$ subjek melebihi harapan (Quinn et al., 2014).

Mueller et al (2017) meneliti dampak latihan daya tahan pada fungsi mitokondria otot rangka pada pasien HD. Penelitian ini menggunakan desain Randomized Controlled Trial untuk membandingkan pasien HD dan subjek sehat. Temuan menunjukkan bahwa mitokondria otot rangka pada pasien HD merespon stimulus latihan daya tahan dengan cara yang sama seperti pada kelompok kontrol. Pelatihan daya tahan adalah pilihan yang aman dan layak untuk meningkatkan indeks metabolisme energi pada otot rangka pasien HD.

Zinzi et al. (2007) melakukan jenis penelitian yang berbeda. Berdasarkan hasil penelitian tersebut, terdapat peningkatan yang sangat signifikan dalam kinerja motorik dan aktivitas kehidupan sehari-hari setelah subjek dengan HD diberikan intervensi berupa aktivitas fisik. Penelitian ini didukung oleh Piira et al. (2013), yang menemukan bahwa latihan fisik meningkatkan fungsi keseimbangan dan gaya berjalan pada pasien HD yang menjalani rehabilitasi intensif. Namun demikian, penelitian lain oleh Piira et al. (2014) memberikan hasil yang sedikit mengecewakan. Selain itu, jumlah subjek yang sedikit dan kurangnya kelompok kontrol mungkin menjadi keterbatasan dalam penelitian tersebut.

Penelitian oleh Quinn et al (2016) meneliti tentang program latihan multi-modal jangka pendek pada individu dengan HD. Penelitian ini menggunakan rancangan Randomized Controlled Trial yang membandingkan kelompok latihan dan kontrol (perawatan

biasa). Temuan dalam penelitian ini mengungkapkan bahwa intervensi latihan multi-modal aman dan layak. Selain itu, ditemukan bahwa intervensi tersebut dapat mengurangi kejadian jatuh serta meningkatkan kebugaran dan fungsi motorik pasien HD.

Meskipun sebagian besar hasil penelitian dalam review ini menunjukkan bahwa aktivitas fisik memiliki efek positif pada penderita $\mathrm{HD}$, beberapa keterbatasan dalam penelitian-penelitian tersebut dapat menyebabkan ketidakakuratan dalam penarikan kesimpulan. Sebagian besar penelitian dalam review ini memiliki ukuran sampel yang relative kecil dan tidak terdapat perhitungan ukuran sampel. Faktanya, ukuran sampel berpengaruh pada kekuatan statistik (statistical power). Semakin kecil sampelnya, semakin lebar interval kepercayaannya, dan semakin kurang presisi hasilnya (Loney et al., 1998). Namun, pemberian latihan juga menjadi kendala untuk perekrutan subjek karena penderita HD memiliki hambatan fisik dan psikiatri, uji coba obat, dan kurangnya motivasi. Selain itu, beberapa penelitian dalam review ini melaporkan ukuran efek intervensi, yang dapat digunakan untuk menggambarkan efek intervensi. Nilai yang lebih tinggi menunjukkan efek yang lebih kuat.

Kedua, beberapa alat ukur yang digunakan di sebagian besar penelitian belum terbukti valid dan reliable untuk penderita HD. Busse et al (2014) melaporkan bahwa versi singkat dari Physical Performance Test (PPT), Berg Balance Scale (BBS), Tinetti Mobility Test (TMT), dan Timed 'Up and Go' Test (TUG) dapat mengukur mobilitas pada penderita HD.

Beberapa penelitian telah menggunakan blinded assessor dan 
desain Randomized-control trial (RCT). RCT telah diakui sebagai golden standard (baku emas) untuk menilai efektifitas perawatan dan menyelidiki efek kausal dari variabel (Muijis, 2004; Armor et al., 2012). Namun, kurangnya uji klinis berskala besar pada penderita HD mungkin menjadi kekurangan lain dalam semua penelitian tersebut.

Sebagian besar penelitian dalam review ini menunjukkan bahwa aktivitas fisik dan latihan memiliki efek positif pada penderita HD. Aktivitas fisik dan latihan dapat meningkatkan kemampuan berjalan, keseimbangan, dan aktivitas hidup sehari-hari pada tahap awal hingga menengah pada HD. Namun, penelitian dalam review ini juga memiliki keterbatasan, seperti dari segi desain penelitian, alat ukur yang kurang tepat, dan jumlah sampel penelitian yang kecil, yang berpotensi menyebabkan bias dalam melaporkan hasil. Penelitian klinis dengan jumlah sampel yang lebih besar selanjutnya dibutuhkan untuk memberikan bukti yang lebih andal tentang efek aktivitas fisik dan latihan dalam meningkatkan kapasitas penderita HD dalam melakukan aktivitas kehidupan sehari-hari.

Meskipun demikian, penelitian tersebut memiliki keterbatasan, seperti dalam hal desain penelitian, tidak adanya blinded assessor, alat ukur atau instrumen penelitian yang tidak efektif, dan ukuran sampel yang kecil, yang dapat menyebabkan bias dalam menyajikan hasil. Oleh karena itu, uji klinis dengan skala yang lebih besar dan pelaporan yang yang lebih baik diperlukan pada penelitian selanjutnya untuk memberikan bukti yang lebih kuat mengenai efektifitas aktivitas fisik dan latihan dalam mengoptimalkan fungsi dan mengurangi gejala pada penderita HD.

\section{KESIMPULAN}

Aktivitas fisik atau latihan terbukti dapat membantu penderita penyakit Huntington (HD). Namun, hanya terdapat beberapa penelitian yang telah dilakukan untuk menguji efektivitas latihan fisik untuk penderita HD. Sebagian besar penelitian dalam review ini menunjukkan bahwa latihan fisik memiliki efek yang menguntungkan pada penderita $\mathrm{HD}$, terutama dalam meningkatkan kemampuan berjalan, keseimbangan, dan aktivitas hidup sehari-hari pada tahap awal hingga menengah.

\section{DAFTAR PUSTAKA}

Aleksandar, V. (2013). Treatment of Huntington Disease Aleksandar. Current Treatment Options in Neurology, 15(4), 424-438. https://doi.org/10.1007/s1194 0-013-0219-8. Treatment

Armour, K., \& MacDonald, D. (Eds.). (2012). Research methods in physical education and youth sport. Routledge.

Bilney, B., Morris, M. E., \& Perry, A. (2003). Effectiveness of physiotherapy, occupational therapy, and speech pathology for people with Huntington's disease: A systematic review. Neurorehabilitation and Neural Repair, 17(1), 12-24. https: / / doi.org/10.1177/08884 39002250448

Bohlen, S., Ekwall, C., Hellström, K., Vesterlin, H., Björnefur, M., Wiklund, L., \& Reilmann, R. (2013). Physical therapy in Huntington's disease - toward objective assessments? European Journal of Neurology, 20(2), 389-393. https://doi.org/10.1111/j.146 8-1331.2012.03760.x

Borgs, L., D., J., Malgrange, B., \& Nguye, L. (2012). Huntington's Disease: From the Physiological 
Function of Huntingtin to the Disease. Huntington's Disease Core Concepts and Current Advances, May 2014. https://doi.org/10.5772/31789

Busse, M., Quinn, L., Debono, K., Jones, K., Collett, J., Playle, R., Kelly, M., Simpson, S., Backx, K., Wasley, D., Dawes, H., \& Rosser, A. (2013). A randomized feasibility study of a 12-week community-based exercise program for people with Huntington's disease. Journal of Neurologic Physical Therapy, 37(4), 149-158. https://doi.org/10.1097/NPT.0 000000000000016

Busse, M., Quinn, L., Khalil, H., McEwan, K., Bunnnig, K., Collett, J., Guedes, L. C., Dawes, H., Ferreira, J., Handley, O., Hannam, C., Howard, E., Sheridan, B., Teal, J., Fritz, N., Kegelmeyer, D., Kloos, A., Bos, R., Dumas, E. M., ... Weekes, R. (2014). Optimising Mobility Outcome Measures in Huntington's Disease. Journal of Huntington's Disease, 3(2), 175-188.

https://doi.org/10.3233/JHD140091

Ekwall, C. (2011). Physiotherapy for patients with huntington's disease: Effects of a treatment program and the intercorrelation between assessment tools. Physiotherapy (United Kingdom), 97, eS304-eS305. https: / /www.embase.com/sea $\mathrm{rch} /$ results?subaction=viewreco rd\&id=L71882590\&from=export \%0Ahttp://dx.doi.org/10.1016/ j.physio.2011.04.002

Frank, S. (2014). Treatment of Huntington's Disease. Neurotherapeutics, 11(1), 153160.

https: / /doi.org/10.1007/s1331 1-013-0244-z

Frese, S., Petersen, J. A., LigonAuer, M., Mueller, S. M., Mihaylova, V., Gehrig, S. M., Kana, V., Rushing, E. J., Unterburger, E., Kägi, G., Burgunder, J. M., Toigo, M., \& Jung, H. H. (2017). Exercise effects in Huntington disease. Journal of Neurology, 264(1), 32-39.

https://doi.org/10.1007/s0041 5-016-8310-1

Harrison, D. J., Busse, M., Openshaw, R., Rosser, A. E., Dunnett, S. B., \& Brooks, S. P. (2013). Exercise attenuates neuropathology and has greater benefit on cognitive than motor deficits in the R6/1 Huntington's disease mouse model. Experimental Neurology, 248, 457-469. https://doi.org/10.1016/j.exp neurol.2013.07.014

Khalil, H., Quinn, L., Van Deursen, R., Dawes, H., Playle, R., Rosser, A., \& Busse, M. (2013). What effect does a structured home-based exercise programme have on people with Huntington's disease? A randomized, controlled pilot study. Clinical Rehabilitation, 27(7), $\quad$ 646-658. https: / / doi.org/10.1177/02692 15512473762

Kloos, A. D., Fritz, N. E., Kostyk, S. K., Young, G. S., \& Kegelmeyer, D. A. (2013). Video game play (Dance Dance Revolution) as a potential exercise therapy in Huntington's disease: A controlled clinical trial. Clinical Rehabilitation, 27(11), 972982.

https://doi.org/10.1177/02692 15513487235

Living Well. (n.d.). Huntington's Disease Association. https: / /www.hda.org.uk/getti ng-help/if-youre-at-risk/living- 
well

Mueller, S. M., Gehrig, S. M., Petersen, J. A., Frese, S., Mihaylova, V., Ligon-Auer, M., Khmara, N., Nuoffer, J. M., Schaller, A., Lundby, C., Toigo, M., \& Jung, H. H. (2017). Effects of endurance training on skeletal muscle mitochondrial function in Huntington disease patients. Orphanet Journal of Rare Diseases, 12(1), 1-7. https://doi.org/10.1186/s1302 3-017-0740-z

Myers, R. H. (2004). Huntington's disease Genetics of Huntington 's disease. 1, 1-5.

Piira, A., van Walsem, M. R., Mikalsen, G., Nilsen, K. H., Knutsen, S., \& Frich, J. C. (2013). Effects of a One Year Intensive Multidisciplinary Rehabilitation Program for Patients with Huntington's Disease: A Prospective Intervention Study. PLOS Currents, SEP, 0-18. https: / /doi.org/10.1371/curre nts.hd.9504af71e0d1f87830c25 c394be47027

Piira, A., van Walsem, M. R., Mikalsen, G., Øie, L., Frich, J. C., \& Knutsen, S. (2014). Effects of a Two-Year Intensive Multidisciplinary Rehabilitation Program for Patients with Huntington's Disease: a Prospective Intervention Study. PLoS Currents, December. https://doi.org/10.1371/curre nts.hd.2c56ceef7f9f8e239a59e cf2d94cddac

Quinn, L., Debono, K., Dawes, H., Rosser, A. E., Nemeth, A. H., Rickards, H., Tabrizi, S. J., Quarrell, O., Trender-Gerhard, I., Kelson, M. J., Townson, J., Busse, M., Akhtar, S., Crooks, J., De Souza, J., Gibson, K., Jones, C., Johnston, C., Jones, K., ... Taylor, C. (2014). Taskspecific training in Huntington disease: A randomized controlled feasibility trial. Physical Therapy, 94(11), 15551568.

https://doi.org/10.2522/ptj.20 140123

Quinn, L., Hamana, K., Kelson, M., Dawes, H., Collett, J., Townson, J., Roos, R., van der Plas, A. A., Reilmann, R., Frich, J. C., Rickards, H., Rosser, A., \& Busse, M. (2016). A randomized, controlled trial of a multi-modal exercise intervention in Huntington's disease. Parkinsonism and Related Disorders, 31, 46-52. https://doi.org/10.1016/j.park reldis.2016.06.023

Quinn, L., Kegelmeyer, D., Kloos, A., Rao, A. K., Busse, M., \& Fritz, N. E. (2020). Clinical recommendations to guide physical therapy practice for Huntington disease. Neurology, 94(5), 217-228. https://doi.org/10.1212/WNL. 0000000000008887

Trembath, M. K., Horton, Z. A., Tippett, L., Hogg, V., Collins, V. R., Churchyard, A., Velakoulis, D., Roxburgh, R., \& Delatycki, M. B. (2010). A retrospective study of the impact of lifestyle on age at onset of huntington disease. Movement Disorders, 25(10), 1444-1450. https://doi.org/10.1002/mds.2 3108

Varda, E., Demetriou, C. A., Heraclides, A., Christou, Y. P., \& Zamba-Papanicolaou, E. (2016). Quality of Life of Cypriot Patients Suffering with Huntington's Disease. PLOS currents, 8, ecurrents.hd. $270776 c 4 f d d 7776$ 499dd45bf47049a75.

https: / /doi.org/10.1371/curre nts.hd.270776c4fdd7776499dd4 5bf47049a75

Weydt, P., Soyal, S. M., 
Landwehrmeyer, G. B., \& Patsch, W. (2014). A single nucleotide polymorphism in the coding region of $\mathrm{PGC}-1 \mathrm{a}$ is a male-specific modifier of Huntington disease age-atonset in a large european cohort. BMC Neurology, 14(1), 1-5.

https: //doi.org/10.1186/14712377-14-1

Zinzi, P., Salmaso, D., De Grandis, R., Graziani, G., Maceroni, S., Bentivoglio, A., Zappata, P., Frontali, M., \& Jacopini, G. (2007). Effects of an intensive rehabilitation programme on patients with Huntington's disease: A pilot study. Clinical Rehabilitation, 21(7), 603-613. https://doi.org/10.1177/02692 15507075495 